\title{
Pengaruh Independensi dan Gaya Kepemimpinan Pada Skeptisisme Profesional Auditor
}

\author{
Ida Ayu Putu Dhaniar Waghmi Pratami ${ }^{1}$ \\ I Ketut Budiartha ${ }^{2}$
}

${ }^{1,2}$ Fakultas Ekonomi dan Bisnis Universitas Udayana (Unud), Bali, Indonesia e-mail: dhaniarwaghmipratami@yahoo.com

\begin{abstract}
ABSTRAK
Auditor yang menerapkan sikap skeptisisme profesional akan kritis dalam melakukan penugasan audit memperhitungkan resiko yang ada dan mengumpulkan bukti audit. Agar sikap skeptis dapat dicapai, auditor perlu untuk memperhatikan faktor-faktor yang dapat mempengaruhi sikap skeptisisme professional auditor. Tujuan penelitian ini adalah untuk mengetahui pengaruh independensi dan gaya kepemimpinan pada skeptisisme profesional auditor. Penelitian ini dilakukan di Kantor Akuntan Publik (KAP) Wilayah Denpasar. Jumlah sampel yang diperoleh berdasarkan metode purposive sampling adalah 45 orang. Pengumpulan data menggunakan metode kuesioner. Berdasarkan hasil analisis ditemukan bahwa independensi dan gaya kepemimpinan memiliki pengaruh positif pada skeptisisme profesional auditor.
\end{abstract}

Kata kunci: Independensi, kepemimpinan, skeptisisme professional audit.

\begin{abstract}
Auditors who apply professional skepticism will be critical in conducting audit assignments taking into account existing risks and collecting audit evidence. In order for skepticism to be achieved, auditors need to pay attention to factors that can influence the skepticism of professional auditors. The purpose of this study was to determine the effect of independence and leadership style on professional skepticism of auditors. This research was conducted at the Denpasar Regional Public Accountant Office (KAP). The number of samples obtained based on the purposive sampling method is 45 people. Data collection using the questionnaire method. Based on the results of the analysis it was found that independence and leadership style had a positive influence on the auditor's professional skepticism.

Keywords: Independence, leadership, professional audit skepticism.
\end{abstract}

\section{PENDAHULUAN}

Sikap skeptisisme seorang auditor merupakan sikap yang menunjukkan profesionalnya sebagai seorang auditor dan harus dimiliki ketika mereka melakukan tugasnya, selain mengikuti aturan yang berlaku. SEC (Securities and Exchange Commissionmelakukan penelitian mengenai hal ini dan memperoleh data bahwa rendahnya sikap skeptisisme auditor menjadi salah satu penyebab 
Ida Ayu Dhaniar Waghmi Pratami dan I Ketut Budiartha. Pengaruh ...

gagalnya sebuah pelaksanaan audit. Sebanyak 40 kasus yang dijadikan bahan penelitian oleh SEC (Securities and Exchange Commission, dan diperoleh hasil bahwa sebanyak 60\% kasus terjadinya karena kurangnya skeptisisme profesional para auditor (Arens, et al., 2012).

Kasus semacam ini membawa banyak dampak, baik dampak ekonomis juga dampak social seperti menurunnya nama baik kantor akuntan publik, dan berkurangnya kepercayaan masyarakat serta investor. Kimberly \& Jhordan (2008) dalam penelitiannnya menemukan bahwa auditor dapat meningkatkan keberhasilan dalam mengidentifikasi kecurangan dengan adanya sikap skeptisisme professional. Sikap ini akan mendorong auditor untuk memiliki pikiran yang kritis dan kepekaan yang tinggi terhadap isu-isu yang terjadi dalam pelaksanaan auditnya, dan hal ini tentunya akan mempermudah auditor untuk menemukan hal-hal yang janggal yang terjadi (Umi, et al., 2015).

Independensi merupakan hal utama yang harus dimiliki auditor untuk menopang profesinya. Karakter inilah yang membuat akuntan publik harus mampu menarik kepercayaan klien dan masyarakat, sebab indenpendensi menunjukkan cara kerja seorang auditor dalam menjaga kerahasiaan data dan berfokus pada kebenaran. Indenpendensi menunjukkan kualitas dari seorang akuntan publik. Masyarakat akan membutuhkan jasa-jasa akuntan dengan independensi yang telah diakui masyarakat dan pihak-pihak terkait. Karakter independensi auditor sama halnya dengan kemampuan dalam bidang akuntansi, sama-sama penting, dan sama-sama memberikan pengaruh besar dalam praktiknya (Kurniawan, 2013). Akuntan publik setidaknya memiliki sikap 
independenn dan jauh dari kepentingan manapun dalam organisasi yang menjadi kliennya atau yang menggunakan jasanya (Antle, 1984).

Begitu petingnya independensi auditor membuat hal ini harus dimiliki setiap akuntan publik, dan mereka pun harus tetap menghindari dalam melakukan hal-hal yang membuatnya mampu kehilangan kepercayaan masyarakat (Raya, 2016). Auditor yang menemukan indikasi terjadinya kecurangan dalam pelaksanaan audit memiliki tanggungjawab untuk segera memberitahukan hal tersebut kepada pihak yang memiliki wewenang dalam perusahaan untuk mencegah kecurangan tersebut (Tri, 2013). Independensi auditor kini mulai banyak dipertanyakan mengingat vitalnya fungsi auditor dalam melayani kebutuhan masyarakat dengan semakin tingginya tuntutan hukum bagi kantor akuntan publik (Sapariyah, 2011).

Identifikasi berbagai kecurangan dalam pelaksanaan tugas audit dipengaruhi oleh banyak faktor. Salah satu diantaranya adalah karakter independensi yang dimiliki auditor, yaitu sikap adil dan tidak memiliki kepentingan lain dengan klien dalam memeriksa laporan keuangan dan memberikan kesimpulan atas hasil pemeriksaan (Arens et al., 2012). Independensi menujukkan bahwa auditor melakukan tugasnya sesuai kode etik profesi auditor, tidak memihak apabila teridentifikasi adanya kecurangan dalam pelaksanaan audit (Dewi, 2013). Tidak adanya independensi dan skeptisisme profesional membuat auditor tidak dapat mengidentifikasi kesalahan yang disebabkan karena kecurangan pihak dalam organisasi (Suraida, 2005). 
Ida Ayu Dhaniar Waghmi Pratami dan I Ketut Budiartha. Pengaruh ...

Gaya kepemimpinan menjadi salah satu faktor yang dapat meningkatkan independensi dan skeptisisme. Gaya kepemimpinan (leadership style) diartikan sebagai hal yang dilakukan pemimpin untuk memberikan pengaruh pada bawahannya sehingga orang yang diberikan pengaruh tersebut mau melakukan perintah pemimpin demi mencapai tujuan organisasi. Cara pemimpin mempengaruhi bawahannya sangat mempengaruhi kinerja organisasi, sebab untuk meningkatkan kinerja dibutuhkan bimbingan dan arahan dari seorang pemimpin. Untuk itulah pemimpin membawa peranan penting dalam pencapaian tujuan organisasi. Di Indonesia sendiri gaya kepemimpinan menjadi sebuah isu menarik dan membawa dampak besar dalam kehidupan bangsa dan negara (Putra, 2015).

Kepemimpinan adalah aktivitas untuk mempengaruhi pengikutnya guna mencapai tujuan organisasi, oleh sebab itu setiap pemimpin memiliki gaya yang berbeda-beda dalam memimpin organisasi. Kinerja karyawan semakin meningkat jika seorang pemimpin memiliki gaya kepemimpinan yang baik. Hal ini menunjukkan bahwa jika seorang pemimpin KAP memiliki gaya kepemimpinan yang baik maka auditor dapat meningkatkan rasa percaya diri dan motivasi dalam menyelesaikan pekerjaannya. dengan adanya motivasi dan arahan dari pemimpin untuk mengaudit dengan sifat yang independen dan skeptis yang berarti tidak akan menerima begitu saja penjelasan dari klien, tetapi akan mengajukan pertanyaan untuk memperoleh alasan, bukti dan konfirmasi mengenai obyek yang dipermasalahkan maka akan menimalisir terjadinya kesalahan dalam mengaudit laporan. 
Kepemimpinan menempati peran yang sangat penting dalam operasional suatu organisasi sebagai penentu masa depan organisasi dalam mewujudkan visi, misi, serta tujuan utama suatu organisasi (Shore \& Wayne, 1993). Oleh karena itu salah satu tantangan besar dalam mewujudkan keberhasilan organisasi adalah terletak pada organisasi itu sendiri dan pada kepemimpinan yang diberlakukan dalam organisasi tersebut (Hom et al., 2009). Tugas pemimpin Salah satu tugas atau peran pimpinan yaitu harus bisa mengelola konflik dalam organisasi yang dipimpinnya sehingga setiap konflik itu bisa diselesaikan dengan baik dan tidak ada yang merasa dirugikan. Pemimpin yang menerapkan gaya informal lebih mengutamakan pada pemberian contoh kepada bawahan dan hal ini membuat auditor memiliki kebebasan untuk berkreasi terhadap pekerjaannya (Trisnaningsih, 2007).

Kepemimpinan sangat menentukan keberhasilan suatu organisasi, sebab pemimpin akan mempengaruhi suasana kerja dan motivasi bawahan. Pemimpin KAP yang mampu menerapkan gaya kepemimpinan yang baik dan sesuai dengan iklim organisasi dapat meningkatkan motivasi auditor untuk bekerja dengan baik dan meningkatkan independensi serta skeptisisme profesional. Pemimpin haruslah orang yang memiliki keahlian dan kemampuan untuk membimbing dan memberikan semangat bawahan untuk bertanggungjawab terhadap pekerjaannya dan tentu mengutamakan independensi. Pemimpin KAP hendaknya adalah orang yang mengutamakan kualitas hasil audit melalui peningkatan karakter independensi dan skeptisisme anggota auditor yang dipimpinnya. 
Ida Ayu Dhaniar Waghmi Pratami dan I Ketut Budiartha. Pengaruh ...

Mengingat pentingnya independensi dan skeptisisme yang harus dimiliki auditor dan banyaknya kasus terjadi akibat kurangnya kedua hal tersebut membuat peneliti terkait untuk melakukan penelitian ini. Manfaatnya adalah untuk mengkonfirmasi teori perilaku, teori sikap, dan teori skeptisisme serta memberikan pertimbangan bagi auditor dalam kaitannya dengan independensi dan gaya kepemimpinan terhadap skeptisisme profesional auditor.

Triandis mengembangkan sebuah teori yaitu teori sikap dan perilaku. Teori tersebut menyatakan bahwa perilaku seseorang dipengaruhi oleh sikap yang berhubungan dengan yang ingin mereka lakukan dan resiko dari hal yang dilakukannya. Jazen (1985) dalam Arumsari (2014) memberikan definisi terkait sikap yaitu pernyataan seseorang mengenai tanggapan orang tersebut terhadap objek, orang, atau peristiwa yang terjadi. Faktor personal terdiri dari sikap auditor dalam melakukan audit serta locus of control internal dalam dirinya. Teori sikap dan perilaku ini akan menunjukkan bagaimana seorang auditor menempatkan sikapnya ketika melakukan proses audit.

Filosuf Prancis Rene Descartes (1596 - 1650 M) pertama kali mengembangkan teori skeptisisme. Saifulloh (2016) menyatakan bahwa untuk mencapai sebuah pengetahuan yang sebenarnya maka seseorang harus memiliki keraguan terlebih dahulu. Keraguan tersebut kemudian akan membuat seseorang mencari tau lebih dalam dan terus berusaha untuk memperoleh jawaban atas keraguan tersebut. Auditor perlu memiliki sikap skeptisisme agar dapat meningkatkan kualitas audit. Sikap skeptisisme mendorong auditor untuk tidak 
mudah percaya akan suatu hal dan selalu berusaha untuk menemukan kebenaran dengan selalu bertanya dan kritis terhadap hal-hal janggal yang terjadi.

Teori ini peneliti gunakan untuk menemukan dampak dari situasi yang dihadapi auditor seperti tekanan waktu dalam pelaksanaan pemeriksaan. Dalam melakukan proses audit, auditor dihadapkan pada waktu yang harus diselesaikan tepat sesuai dengan rencana dan standar audit yang berlaku. Tekanan waktu ini kemudian dapat mempengaruhi sikap seseorang. Auditor diharapkan mampu menjadikan batas waktu sebagai motivasi untuk melakukan pekerjaan tepat waktu dan tetap memiliki sikap skeptisisme.

Auditor merupakan sebutan untuk seseorang yang dnegan keahlian yang dimiliki melakukan pemeriksaan terkait laporan keuangan yang disusun sebuah perusahaan, kemudian dari pemeriksaan tersebut disampaikan pendapat apakah telah sesuai dengan prinsip-prinsip akuntansi yang berlaku umum ataukah belum. Pendapat dari auditor tersebut sangat penting dalam kaitannya dengan operasi perusahaan, untuk memastikan kepada masyarakat dan investor bahwa perusahaan tersebut dari segi material layak ataupun tidak dalam menjalankan operasionalnya. Terdapat 3 jenis auditor, diantaranya auditor independen, auditor pemerintah, dan auditor internal yang memiliki perbedaan dari cakupan wilayah kerjanya. Akan tetapi ketiga jenis auditor tersebut memiliki prinsip yang sama yaitu memiliki karakter independensi dan skeptisisme.

Auditor menggunakan pengetahuan, keterampilan, dan kemampuan yang diminta olehprofesi akuntan publik untuk melaksanakan dengan hati-hati dan tuntas itikad baik dan integritas, pengumpulan dan penilaian bukti audit dalam 
Ida Ayu Dhaniar Waghmi Pratami dan I Ketut Budiartha. Pengaruh ...

suatu tujuan(Jaya, Irene, 2016). Profesi sebagai auditor sebenarnya memiliki tanggung jawab yang besar karena berhubungan dengan nama baik suatu perusahaan di mata publik. Untuk itu sudah semestinya auditor harus memiliki kriteria yang benar-benar mumpuni dalam hal pemeriksaan. BPKSTAN pada tahun 2017 memberikan kriteria ideal seorang auditor, yakni memiliki keahlian dan pelatihan teknis yang cukup sebagai seorang auditor, memiliki independensi, dan menggunakan keahlian yang dimiliki dengan cermat, serta bekerja secara profesional.

Independensi merupakan suatu sikap yang tidak mampu dipengaruhi orang lain, tetap pada pendirian, serta bebas dari kendali orang lain (Mulyadi, 2013). Sikap ini menunjukkan auditor selalu berpegang pada fakta yanga da dan juga bukti-bukti pendukung lainnya, serta berdasarkan hal tersebut mampu menyatakan argumennya secara jujur. Independensi merupakan hal yang setidaknya harus dimiliki oleh auditor karena merupakan dasar dari terbentuknya integritas dan objektivitas dalam diri auditor. Hal ini menyebabkan banyak perusahaan yang menggunakan jasa audit eksternal untuk memberikan opini terkait laporan keuangannya(Arens,et al., 2012). Pentingnya independensi auditor mendorong regulator untuk mengatur lamanya periode penugasan auditor di Indonesia untuk meningkatkan independensi (Junaidi, et al, 2016).

Keputusan investasi pemodal sangat bergantung pada opini audit yang berkualitas. Dengan demikian, kualitas auditor adalahpenting tetapi investor tidak tahu cara menilai itu dan mereka mempertimbangkan reputasi dan nama merek auditorsebagai indikator kualitas itu. Kualitas audit yang tinggi dianggap sebagai 
jaminan bahwa laporan keuangan dibuat secara independen(Hua, et al., 2014). Independensi auditor adalah kemampuan auditor untuk mempertahankansikap mental secara objektif dan tidak memihak pada kepentinganklien dalam melakukan audit, menganalisis hasil, dan pengesahan dalam laporan audit. Ini terdiri dari tiga dimensi yaitu independensi pemrograman, independensi investigatif, dan independensi (Saputra, 2015). Tanpa pengakuan perbedaan dalam budaya lokal dan tradisi akuntansi, tidak mungkin untuk mewujudkan independensi auditor meskipun prosedur "sesuai internasional" sedang diikuti (Hom et al., 2009).

Independensi menjadi sangat penting karena berkaitan dnegan kualitas dari laporan audit yang akan dihasilkan. Auditor yang tidak memiliki independensi maka hasil auditannya tidak akan baik dan tidak mendapat kepercayaan masyarakat (Elen \& Mayangsari, 2013). Susanto (2017)memberikan jenis-jenis independensi, yang pertama yaitu independensi senyatanya yang berhubungan dengan tingkat objektivitas auditor, kedua independensi penampilan berkaitan dengan pandangan pihak lain terhadap diri auditor tersebut, dan yang ketiga independensi keahlian yang dilihat dari kemampuan yang dimiliki auditor yang mendukungnya dalam menyelesaikan tugas-tugasnya.

Sikap seperti ini wajib hukumnya bagi auditor karena berkaitan dengan kepercayaan masyarakat. Auditor harus mampu menjaga independensi yang telah dimiliki dan menghindari hal-hal yang mampu mengurangi independensinya karena menciptakan kepercayaan masyarakat bukanlah hal yang mudah. Ketika 
Ida Ayu Dhaniar Waghmi Pratami dan I Ketut Budiartha. Pengaruh ...

masyrakat telah mempercayai suatu KAP tertentu maka mereka akan selalu mengunakan jasa tersebut.

Sebagai seorang pemimpin dalam sebuah perusahaan, ia harus mampu menjalankan kewajibannya untuk memberikan pengaruh kepada orang lain agar bawahannya mau melakukan tugas sesuai dengan kewajiban dan tanggung jawabnya masing-masing, memiliki loyalitas tinggi terhadap organisasi demi tercapainya tujuan organisasi (Sedarmayanti, 2009). Teori kepemimpinan perilaku (behavioral) memberikan penjelasan bahwa kepemimpin yang diterapkan dalam sebuah organisasi akan mempengaruhi efektivitas perkumpulan kerja (Black, 2000). Kinerja unit organisasi dapat meningkat apabila gaya pemimpin dalam mengatur sumber daya manusia sesuai dengan kondisi dalam organisasi tersebut. Teori kepemimpinan perilaku memberikan pandangan bahwa gaya kepemimpinan yang diterapkan manajer dapat dirubah dan dikembangkan sesuai dengan kondisi yang ada dalam organisasi. Sebuah penelitian oleh Trisnaningsih (2007) mengenai pengaruh dari gaya kepemimpinan dan budaya organisasi pada komitmen yang dilihat dari tingkat tanggung jawab dan budaya yang dimiliki setiap negara. Karakter pemimpin yang dimiliki oleh auditor ditunjukkan dari cara auditor dalam menjalin hubungan dengan rekan kerjanya yang lain, dan juga pada bawahannya untuk bekerja sama dalam memperbaiki kinerja dan mencapai visi, misi auditor.

Skeptisisme merupakan sikap auditor dalam mengevaluasi semua bukti yang ada, sehingga tidak melewatkan satu bukti pun, dan hasil auditnya tidak perlu diragukan lagi. Kegagalan audit seringkali terjadi dan salah satu penyebabnya adalah rendahnya sikap skeptisisme yang dimiliki auditor untuk 
mendeteksi segala kecurangan yang dilakukan oleh pihak manajemen perusahaan. Skeptisisme dipengaruhi tidak hanya oleh sikap dari dalam diri sendiri melainkan juga karena pengaruh situasional. Skeptisisme personal yang tinggi dibarengi dengan skeptisisme situasional akan menciptakan keputusan audit yang baik dan berkualitas. Skeptisisme terjadi ketika ada keraguan mengenai keandalan informasi yang diterima. Ketika seorang individu memiliki keraguan mengenai keandalan informasi yang diberikanoleh klien, ia akan mencari lebih banyak indikasi. Dalam hal ini, seorang auditor yang menunjukkanskeptisisme profesional tingkat tinggi akan mencari lebih banyak informasi dan membuat tambahanmemeriksa untuk merumuskan dasar yang cukup untuk penilaian audit lebih lanjut (Hussein, et al.,2016).

Profesi audit adalahselalu dikaitkan dengan etika dan skeptisisme profesional. Namun, masih ada sedikit penelitiandilakukan untuk menganalisis hubungan antara etika dan skeptisisme dalam audit sektor publik (Mapuasari, 2017). Untuk mencegah kecurangan, auditor harus menjadi auditor profesional. Untuk menjadi auditor profesional, auditor harus skeptis. Skeptisisme auditorprofesional adalah sikap auditor yang selalu meragukan dan mempertanyakan segalanya, dan menilai secara kritisbukti audit dan mengambil keputusan audit berdasarkan keahlian audit yang dimilikinya (Warsidi, et al., 2018). Bahkan tanpa menekankanelemen "skeptisisme," auditor harus mengajukan pertanyaan atau keraguan selama proses bukti. Auditor yang tidak memiliki skeptisisme atau pikiran yang mempertanyakan didiskualifikasi dari melakukan audit (Toba, 2011). 
Ida Ayu Dhaniar Waghmi Pratami dan I Ketut Budiartha. Pengaruh ...

Teori sikap memberikan penjelasan mengenai sikap yang harus dimiliki seorang auditor dalam melakukan kegiatan auditing. Sikap yang harus dimiliki seorang auditor adalah independensi yang mendorong auditor untuk tidak memihak kepada siapapun, serta tidak mudah dipengaruhi oleh orang lain. Auditor juga harus memiliki sikap skeptis untuk mendeteksi segala kesalahan yang terjadi. Auditor yang memiliki sikap skeptis dapat mencegah dan mengurangi kemungkinan kecurangan (Koroy \& Ramayana, 2008). Penelitian oleh Bawono \& Singgih (2010)memperoleh hasil bahwa kegagalan audit terutama disebabkan oleh kurangnya independensi dan skeptisisme auditor. Berdasarkan penjelasan diatas, maka hipotesis yang diajukan adalah sebagai berikut.

$\mathrm{H}_{1}$ : Independensi berpengaruh positif pada skeptisme profesional auditor

Teori kepemimpinan menjelaskan mengenai cara pemimpin dalam memberikan bimbingan dan dorongan pada bawahannya untuk melaksanakan tugas sesuai dengan tanggung jawabnya. Kepemimpinan yang baik dna diterima semua anggota dapat menignkatkan motivasi auditor untuk melaksanakan kewajibannya dengan baik dan tepat waktu. Pemimpin dalam KAP juga dapat mengarahkan auditor untuk selalu berpegang pada sikap skeptis dalam menyelesaikan tugas auditingnya, sehingga meminimalisir adanya kesalahan dan kecurangan. Penelitian Arianti, (2014) menunjukkan kinerja auditor dipengauruhi secara positif oleh gaya kepemimpinan. Kepemimpinan demokratis yang diterapkan ternyata mampu meningkatkan semangat kerja bagi pada auditor menurut Berdasarkan penjelasan diatas, maka hipotesis yang diajukan adalah sebagai berikut. 
$\mathrm{H}_{2}$ : Gaya kepemimpinan berpengaruh positif pada skeptisme profesional auditor

\section{METODE PENELITIAN}

Pendekatan yang digunakan dalam penelitian ini adalah penelitian asosiatif, dengan desain penelitian sebagai berikut.

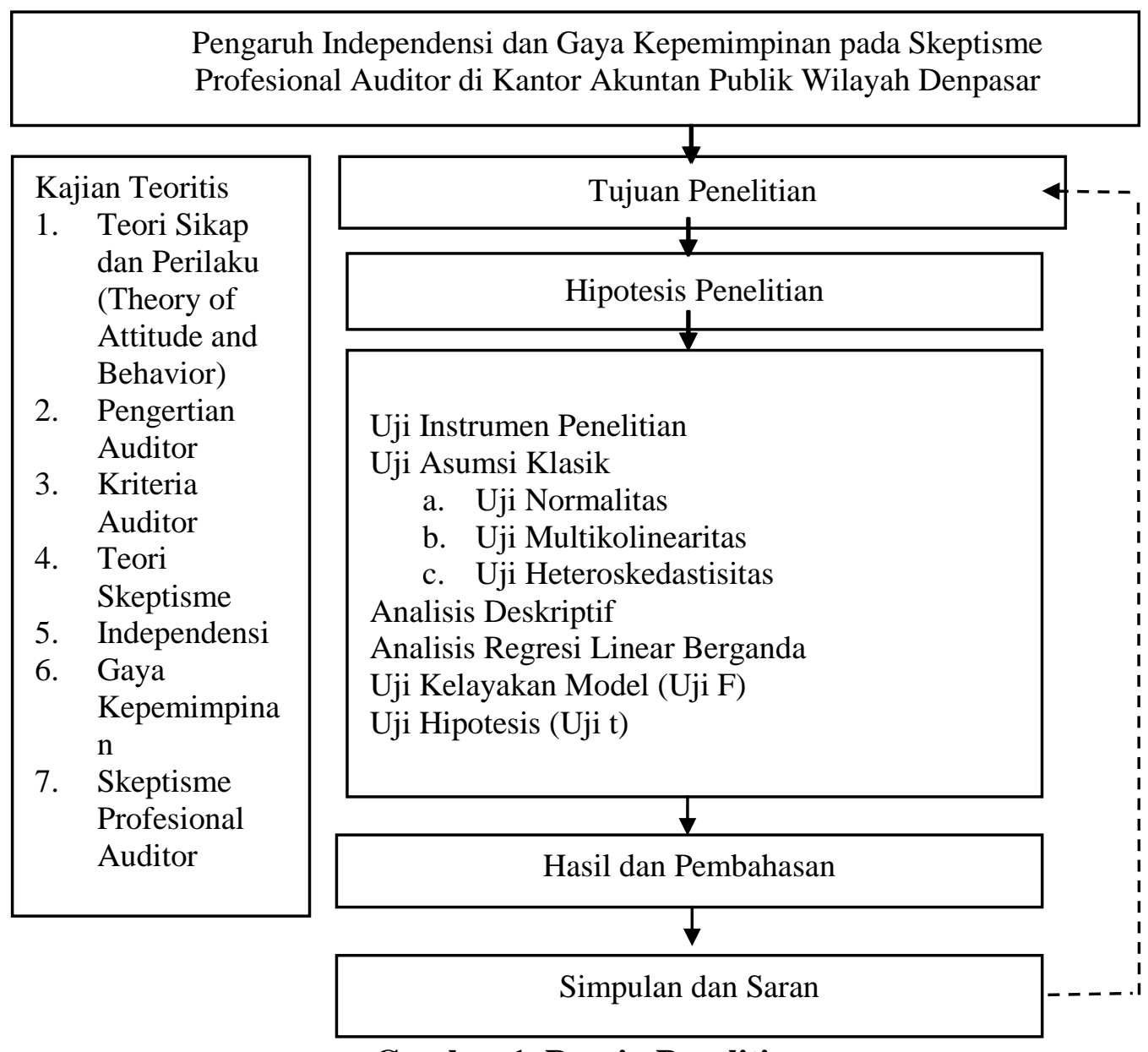

Sumber: Data diolah, 2019

Lokasi penelitian adalah pada seluruh KAP yang terdapat di Kota Denpasar sebanyak 7 kantor, yakni KAP K. Gunarsa, KAP Drs. Ketut Budiartha, Msi., KAP Drs. Ketut Muliartha RM \& Rekan, KAP Arnaya \& Darmayasa, KAP Budhananda Munidewi, KAP Johan Malonda Mustika \& Rekan (Cabang), dan 
Ida Ayu Dhaniar Waghmi Pratami dan I Ketut Budiartha. Pengaruh ...

KAP I Wayan Ramantha dengan menggunakan objek yakni independensi dan kepemimpinan pada sikap skeptisisme auditor.

Sebagai populasi dalam penelitian ini adalah seluruh auditor di KAP Kota Denpasar yang berjumlah 53 orang. Pengambilan sampel menggunakan metode purposive sampling yaitu dengan kriteria tertentu. Pengumpulan data dilakukan dengan metode kuesioner menggunakan 5 Skala Likert, sebagai berikut 1 : sangat tidak setuju (STS), 2 : tidak setuju (TS), 3 : netral (N), 4 : setuju (S), 5: sangat setuju (SS). Analisis regresi berganda digunakan dalam penelitian ini.

Teknik analasis data yang digunakan dalam penelitian ini adalah teknik analisis kuantitatif. Analisis ini meliputi analisis regresi liniear berganda yangdigunakan untuk menganalisis pengaruh variabel independensi $\left(\mathrm{X}_{1}\right)$ dan gaya kepemimpinan $\left(\mathrm{X}_{2}\right)$ terhadap skeptisme profesional auditor dan umumnya dinyatakan dalam persamaan sebagai berikut:

$$
\mathrm{Y}=\mathrm{a}+\beta_{1} \mathrm{X}_{1}+\beta_{2} \mathrm{X}_{2}+\mathrm{e}
$$

Keterangan:

$\mathrm{Y}=$ Skeptisme profesional Auditor

a $\quad=$ Nilai intercept/constant

$\mathrm{X}_{1} \quad=$ Variabel Independensi

$\mathrm{X}_{2} \quad=$ Variabel Gaya Kepemimpinan

$\beta 1, \beta 2=$ Koefisien regresi variabel bebas

e $\quad=$ Standard error (tingkat kesalahan)

\section{HASIL DAN PEMBAHASAN}

Penelitian dengan menyebarkan kuesioner ke enam KAP yang ada di Kota Denpasar dengan rincian sebagai berikut. 
ISSN: 2302-8556

E-Jurnal Akuntansi

Vol.28.1.Juli (2019): 722-747

Tabel 1.

Daftar Penyebaran dan Pengembalian Kuisioner

\begin{tabular}{clcc}
\hline No & \multicolumn{1}{c}{ Nama Kantor Akuntan Publik } & $\begin{array}{c}\text { Kuisioner } \\
\text { Disebar }\end{array}$ & $\begin{array}{c}\text { Kuisioner } \\
\text { Kembali }\end{array}$ \\
\hline 1 & KAP K. Gunarsa & 12 & 12 \\
2 & KAP Drs. Ketut Budiartha, Msi. & 13 & 13 \\
3 & KAP Drs. Ketut Muliartha RM \& Rekan & 7 & 7 \\
4 & KAP Arnaya \& Darmayasa & 2 & 2 \\
5 & KAP Budhananda Munidewi & 6 & 6 \\
6 & KAP Johan Malonda Mustika \& Rekan (Cabang) & 5 & 5 \\
7 & KAP I Wayan Ramantha & 0 & 0 \\
\multicolumn{2}{c}{ Total } & 45 & 45 \\
\hline
\end{tabular}

Sumber: Data diolah, 2019

Peneliti menggunakan seluruh kuesioner yang kembali yaitu sebanyak 45 buah kuesioner. Syarat yang harus dipenuhi suatu item pertanyaan untuk digunakan dalam penelitian ini adalah nilai korelasi faktor bernilai di atas 0,3 seperti berikut.

Tabel 2. Hasil Uji Validitas

\begin{tabular}{|c|c|c|c|}
\hline Variabel & Indikator & $\begin{array}{c}\text { Koefisien } \\
\text { Korelasi }\end{array}$ & Keterangan \\
\hline & Y1 & 0,434 & Valid \\
\hline & Y2 & 0,482 & Valid \\
\hline & Y3 & 0,590 & Valid \\
\hline & Y4 & 0,698 & Valid \\
\hline Skeptisme & Y5 & 0,648 & Valid \\
\hline Profesional & Y6 & 0,679 & Valid \\
\hline \multirow{5}{*}{$\begin{array}{l}\text { Auditor } \\
\text { (Y) }\end{array}$} & Y7 & 0,687 & Valid \\
\hline & Y8 & 0,444 & Valid \\
\hline & $\mathrm{X} 1.1$ & 0,763 & Valid \\
\hline & $\mathrm{X} 1.2$ & 0,544 & Valid \\
\hline & $\mathrm{X} 1.3$ & 0,659 & Valid \\
\hline \multirow{8}{*}{$\begin{array}{l}\text { Independensi } \\
\qquad\left(\mathrm{X}_{1}\right)\end{array}$} & X1.4 & 0,743 & Valid \\
\hline & $X 1.5$ & 0,726 & Valid \\
\hline & X1.6 & 0,621 & Valid \\
\hline & X1.7 & 0,650 & Valid \\
\hline & $\mathrm{X} 2.1$ & 0,617 & Valid \\
\hline & X2.2 & 0,461 & Valid \\
\hline & $\mathrm{X} 2.3$ & 0,623 & Valid \\
\hline & X2.4 & 0,488 & Valid \\
\hline \multirow{4}{*}{$\begin{array}{c}\text { Gaya } \\
\text { Kepemimpinan } \\
\left(\mathrm{X}_{2}\right)\end{array}$} & $X 2.5$ & 0,510 & Valid \\
\hline & X2.6 & 0,706 & Valid \\
\hline & X2.7 & 0,744 & Valid \\
\hline & $\mathrm{X} 2.8$ & 0,657 & Valid \\
\hline
\end{tabular}

Sumber : Data diolah, 2019 
Ida Ayu Dhaniar Waghmi Pratami dan I Ketut Budiartha. Pengaruh ...

Reliabilitas adalah derajat ketepatan, ketelitian atau keaukuratan yang ditunjukan oleh instrument pengakuan dimana pengujiannya dapat dilakukan secara internal, yaitu pengujian dengan menganalisis konsistensi butir-butir yang ada. Suatu instrument dikatakan reliabel, jika instrument tersebut memiliki nilai Alpha Cronbach lebih dari 0.60.

Tabel 3.

Hasil Uji Reliabilitas

\begin{tabular}{lcc}
\hline \multicolumn{1}{c}{ Variabel } & $\begin{array}{c}\text { Nilai Cronbach's } \\
\text { Alpha }\end{array}$ & Keterangan \\
& 0,798 & \\
\hline Independensi (X1) & 0,751 & Reliabel \\
Gaya Kepemimpinan (X2) & 0,720 & Reliabel \\
Skeptisisime Profesional Auditor (Y) & Reliabel \\
\hline Sumber: Data diolah, 2019 &
\end{tabular}

Analisis regresi linear berganda yang digunakan dalam penelitian ini harus melalui dan lolos dalam uji asumsi klasik terlebih dahulu. Uji normalitas merupakan uji yang pertama dengan melihat nilai Asymp. Sig (2-tailed) lebih besar dari 0,05 , sebagai berikut.

Tabel 4.

Hasil Uji Normalitas Data

\begin{tabular}{llr}
\hline & & Unstandardized Residual \\
\hline $\mathrm{N}$ & & 45 \\
Normal Parameters & Mean &, 0000000 \\
& Std. Deviation & 1,881748856 \\
Most Extreme Differences & Absolute & .107 \\
& Positive & .058 \\
& Negative & -.107 \\
Test Statistic & &, 715 \\
Asymp. Sig. (2-tailed) & & .686 \\
\hline Sumber $:$ Data diolah, 2019 & &
\end{tabular}

Sesuai dengan tabel di atas, maka data telah lolos uji normalitas karena nilai Asymp. Sig (2-tailed) 0,686 berada di atas 0,05. 
Uji kedua dalam asumsi klasik adalah uji multikolinearitas dengan nilai tolerance lebih dari $10 \%$ atau VIF kurang dari 10 agar data dapat dikatakan lolos uji ini, seperti yang ditunjukkan dalam tabel berikut.

Tabel 5.

Hasil Uji Multikolinieritas

\begin{tabular}{lcc}
\hline \multirow{2}{*}{ Variabel } & \multicolumn{2}{c}{ Collinearity Statistic } \\
\cline { 2 - 3 } & Tolerance & VIF \\
\hline Independensi $\left(\mathrm{X}_{1}\right)$ & 0,425 & 2,355 \\
Gaya Kepemimpinan $\left(\mathrm{X}_{2}\right)$ & 0,425 & 2,355 \\
\hline Sumber: Data diolah, 2019 & \multicolumn{2}{c}{. }
\end{tabular}

Sumber: Data diolah, 2019

Tabel 5 menunjukkan bahwa data layak untuk diteliti karena tidak mengandung gejala multikolinearitas.

Selanjutnya adalah uji heteroskedastisitas untuk mengetahui varian dari suatu data melalui uji glejser dengan melihat nilai signifikansi yang harus berada di atas 0,05 , seperti tabel di bawah ini.

Tabel 6.

Hasil Uji Heteroskedastisitas

\begin{tabular}{lcc}
\hline \multicolumn{1}{c}{ Variabel } & Sig. & Keterangan \\
\hline Independensi $\left(\mathrm{X}_{1}\right)$ & 0,487 & Bebas Heteroskedastisitas \\
Gaya Kepemimpinan $\left(\mathrm{X}_{2}\right)$ & 0,679 & Bebas Heteroskedastisitas \\
\hline
\end{tabular}

Sumber : Data diolah, 2019

Berdasarkan tabel tersebut diketahui bahwa data tidak mengandung heteroskedastisitas sehingga layak untuk diteliti.

Uji asumsi klasik menunjukkan bahwa data telah lolos dan bisa dilanjutkan ke analisis regresi linear berganda sebagai berikut. 
Tabel 7.

Hasil Analisis Regresi Linier Berganda

\begin{tabular}{|c|c|c|c|c|c|}
\hline \multirow[t]{2}{*}{ Model } & \multicolumn{2}{|c|}{$\begin{array}{c}\text { Unstandardized } \\
\text { Coefficients }\end{array}$} & \multirow{2}{*}{$\begin{array}{c}\text { Standardized } \\
\text { Coefficients }\end{array}$} & \multirow[t]{2}{*}{$\mathrm{T}$} & \multirow[t]{2}{*}{ Sig } \\
\hline & $\mathrm{B}$ & $\begin{array}{l}\text { Std. } \\
\text { Error }\end{array}$ & & & \\
\hline (Constant) & 5,740 & 2,255 & & 2,545 & 0,015 \\
\hline Independensi $\left(\mathrm{X}_{1}\right)$ & 0,595 & 0,112 & 0,613 & 5,301 & 0,000 \\
\hline Gaya Kepemimpinan $\left(\mathrm{X}_{2}\right)$ & 0,294 & 0,110 & 0,310 & 2,683 & 0,010 \\
\hline Adjusted $\mathrm{R}^{2}$ & & & & & 0,750 \\
\hline $\mathrm{F}$ & & & & & 66,958 \\
\hline Sig. F & & & & & 0,000 \\
\hline
\end{tabular}

Sumber: Data diolah, 2019

Persamaan regresi dalam penelitian ini adalah berikut.

$$
\mathrm{Y}=5,740+0,595 \mathrm{X}_{1}+0,294 \mathrm{X}_{2}+\mathrm{e}
$$

Nilai konstanta sebesar 5,740 berarti apabila independensi $\left(\mathrm{X}_{1}\right)$ dangaya kepemimpinan $\left(\mathrm{X}_{2}\right)$ memiliki tanda positif maka auditor sudah memiliki sikap skeptisme profesional auditor. Nilai koefisien regresi Independensi $\left(\mathrm{X}_{1}\right)$ sebesar 0,595, berarti menunjukan bahwa independensi mempunyai hubungan positif terhadap skeptisme profesional auditor. Artinya bahwa independensi berpengaruh positif dengan skeptisme profesional auditor. Hal ini menunjukan bahwa ketika independensi semakin baik maka skeptisme profesional auditor juga cenderung baik.

Nilai koefisien regresi Gaya Kepemimpinan $\left(\mathrm{X}_{2}\right)$ sebesar 0,294, berarti menunjukan bahwa gaya kepemimpinan mempunyai hubungan positif terhadap skeptisme profesional auditor. Artinya bahwa gaya kepemimpinan berpengaruh positif dengan skeptisme profesional auditor. Hal ini menunjukan bahwa ketika gaya kepemimpinan semakin baik maka skeptisme profesional auditor juga cenderung baik. 
Nilai signifikansi $\mathrm{F}$ adalah 0,000 kurang dari 0,05 menunjukkan kelayakan model ini untuk diteliti serta menunjukkan bahwa independensi dan gaya kepemimpinan berpengaruh pada skeptisisme auditor. Adjusted $R$ Square sebesar 0,750 mempunyai arti bahwa sebesar $75,0 \%$ variasi skeptisme professional auditor dipengaruhi oleh variasi independensi dan gaya kepemimpinan, sedangkan sisanya sebesar 25,0\% dijelaskan oleh faktor lainnya seperti kompetensi dan etika.

Tingkat signifikan t dalam variabel independensi sebesar 0,000 yang berarti lebih kecil atau dibawah nilai $\alpha=0,05$. Hal ini menunjukan bahwa independensi berpengaruh secara positif signifikan pada skeptisme profesional auditor.

Auditor dengan karakter independensi yang tinggi, tidak dengan mudah mendengarkan omongan orang lain, tidak mudah terpengaruh dan tidak memihak. Mereka akan cenderung meragukan semua hal tanpa dibarengi bukti yang mendukung. Sifat seperti ini tentu akan meningkatkan skeptisisme auditor dan mendorong mereka untuk mencari tau lebih dalam terkait hal-hal yang masih dirasa janggal oleh mereka. Fraud terjadi disebabkan oleh kurangnya skeptisisme auditor, oleh karena itu independensi sangat penting untuk meningkatkan skeptisisme auditor dan meningkatkan kualitas auditnya.

Variabel gaya kepemimpinan memiliki tingkat signifikan t sebesar 0,010 yang berarti lebih kecil atau dibawah nilai $\alpha=0,05$. Hal ini menunjukan bahwa gaya kepemimpinan berpengaruh secara positif pada skeptisme profesional auditor. Kepemimpinan yang baik dan diterima semua anggota organisasi cenderung dapat mendorong auditor untuk melakukan kewajibannya sesuai 
Ida Ayu Dhaniar Waghmi Pratami dan I Ketut Budiartha. Pengaruh ...

dengan standar yang berlaku, mengutamakan kualitas dengan meningkatkan skeptisisme dalam mendeteksi kecurangan yang terjadi. Pemimpin sangat penting peranannya dalam memberikan motivasi dan bimbingan kepada bawahan untuk bertindak sesuai aturan dan menuju pada tujuan organisasi.

Uji statistik t pada dasarnya dilakukan untuk menunjukan seberapa jauh pengaruh satu variabel independen secara individual dalam menerangkan variabel-variabel dependen. Uji statistik dilakukan dengan membandingkan hasil nilai signifikansi dengan $\alpha=0,05$ dan dapat dijelaskan pada Tabel 8 .

Tabel 8.

Hasil Analisis Uji Statistik t

\begin{tabular}{lcrrr}
\hline Variabel & $\begin{array}{c}\text { Koefisien } \\
\text { Regresi }\end{array}$ & $\mathrm{T}_{\text {hitung }}$ & \multicolumn{1}{l}{ Sig. } & Hasil Hipotesis \\
\hline $\mathrm{X}_{1}$ & 0,613 & 5,301 & 0,000 & $\mathrm{H}_{1}$ Diterima \\
$\mathrm{X}_{2}$ & 0,310 & 2,683 & 0,010 & $\mathrm{H}_{1}$ Diterima \\
\hline \multicolumn{2}{l}{ Sumber: Data diolah, 2019} & & &
\end{tabular}

Berdasarkan Tabel 8. hasil analisis pengaruh independensi terhadap skeptisme profesional auditor diperoleh nilai sig. $\mathrm{t}$ sebesar 0,000 dengan nilai koefisien beta 0,613. nilai sig. $\mathrm{t} 0,000<0,05$ mengindikasikan bahwa independensiberpengaruh positif terhadap skeptisme profesional auditor sehingga hipotesis pertama dalam penelitian ini diterima. Dan berdasarkan hasil analisis pengaruh gaya kepemimpinan terhadap skeptisme profesional auditor diperoleh nilai sig. $\mathrm{t}$ sebesar 0.010 dengan nilai koefisien beta 0,310 . Nilai sig. $\mathrm{t} 0,010<0,05$ mengindikasikan bahwa gaya kepemimpinanberpengaruh positif terhadap skeptisme profesional auditor sehingga hipotesis kedua dalam penelitian ini diterima. 
Berdasarkan dari hasil uji statistik t diketahui bahwa tingkat signifikan $\mathrm{t}$ sebesar 0,000 yang berarti lebih kecil atau dibawah nilai $\alpha=0,05$. Hal ini menunjukan bahwa independensi berpengaruh secara positif signifikan pada skeptisme profesional auditor. Hal ini terjadi adanya pengaruh antara independensi dan skeptisme profesional auditor, bahwa dengan adanya sikap independensi ini akan memperkuat sikap kritis dan teliti terhadap bukti-bukti yang dikumpulkan untuk meniali kewajaran laporan keuangan yang disebut dengan sikap skeptisme profesional auditor. Penelitian Bawono \& Singgih (2010) meyatakan kegagalan audit cenderung disebabkan karena kurangnya sikap skeptisme profesional auditor, oleh karena itu jika seorang auditor memiliki sifat yang skeptis maka akan dapat mengurangi kecenderungan orang yang melakukan fraud (Koroy, 2008).

Berdasarkan dari hasil tingkat signifikan $\mathrm{t}$ diketahui bahwa tingkat signifikan $\mathrm{t}$ sebesar 0,010 yang berarti lebih kecil atau dibawah nilai $\alpha=0,05$. Hal ini menunjukan bahwa gaya kepemimpinan berpengaruh secara positif pada skeptisme profesional auditor. Hasil penelitian dari Arianti, (2015) menyatakan jika gaya kepemimpinan berpengaruh positif terhadap kinerja auditor.Gaya kepemimpinan yang demokratis dapat mendorong semangat kerja auditor dalam menyelesaikaan tugas auditnya (Suryagita, 2018).

Hal ini menunjukkan bahwa jika seorang pemimpin dalam kantor akuntan publik memiliki gaya kepemimpinan yang baik maka auditor dapat meningkatkan rasa percaya diri dan motivasi dalam menyelesaikan pekerjaannya dengan adanya motivasi dan arahan dari pemimpin untuk mengaudit dengan sifat yang skeptis 
Ida Ayu Dhaniar Waghmi Pratami dan I Ketut Budiartha. Pengaruh ...

yang berarti tidak akan menerima begitu saja penjelasan dari klien, tetapi akan mengajukan pertanyaan untuk memperoleh alasan, bukti dan konfirmasi mengenai obyek yang dipermasalahkan maka akan menimalisir terjadinya kesalahan dalam mengaudit laporan.

\section{SIMPULAN}

Independensi merupakan sikap yang harus dimiliki oleh seorang auditor. Independensi menunjukkan bahwa auditor tidak terpengaruh oleh orang lain dan tidak memihak siapapun dalam menjalankan tugasnya. Sikap seperti itu akan mendorong auditor untuk bekerja secara teliti dan memiliki keraguan terhadap setiap kejanggalan yang ditemukan selama proses auditing. Kepemimpinan juga merupakan faktor yang tidak kalah penting dalam mendorong auditor bersikap lebih skeptis dalam pekerjaannya. Pemimpin yang baik cenderung memberikan arahan dan dorongan serta motivasi pada auditor untuk menignkatkan kualias audit sehingga mampu meningkatkan kepercayaan masyarakat terhadapnya. Auditor yang bekerja di KAP yang tersebar di Kota Denpasar dan seluruh KAP di Indonesia hendaknya terus meningkatkan sikap independensi dan menerapkan gaya kepemimpinan yang baik untuk menumbuhkan sikap skeptisisme dalam menjalankan kewajibannya.

Berdasarkan simpulan yang telah diuraikan, maka dapat disampaikan beberapa saran sebagai berikut:

Bagi Kantor Akuntan Publik (KAP) sebaiknya memperhatikan sikap independensi dan meningkatkan gaya kepemimpinan yang dapat mempengaruhi 
skeptisme professional auditor. Bagi auditor sendiri, hendaknya terus berupaya meningkatkan independensi dan sikap skeptis terhadap laporan yang diperiksa agar terciptanya laporan yang baik.

\section{REFERENSI}

Antle, R. (1984). Auditor Independence. Journal of Accounting Research, 22(1), 1. https://doi.org/10.2307/2490699

Arens, A, A., Beasley, M. S., \& Elder, R. J. (2012). Auditing and Assurance Service. England: Pearson Education Limited.

Arianti. (2014). Pengaruh Obyektifitas, dan Akuntabilitas Terhadap Kualitas Audit di Pemerintahan Daerah (Studi Pada Inspektorat Kabupaten Buleleng). E-Journal S1 Akuntansi Universitas Pendidikan Ganesha Jurusan Akuntansi S1, 2(1).

Arumsari, V. F. (2014). Pengaruh good Corporate governance terhadap Kinerja Keuangan bank Syariah. Universitas Muhammadiyah Surakarta.

Bawono, I. R., \& Singgih, E. M. (2010). Faktor-Faktor dalam Diri Auditor dan Kualitas Audit, Studi pada KAP "Big Four" di Indonesia. Jurnal Akuntansi Dan Auditing Indonesia.

Black, S. B. and B. (2000). Board Independence and Long-Term Firm Performance, 2000(February), 1-44.

Dewi, R. (2013). Pengaruh Etika Profesi, Komitmen Profesional, Pengalaman Kerja, dan Independensi Auditor terhadap Pengambilan Keputusan untuk Memberikan Opini Audit. Universitas Udayana.

Elen, T., \& Mayangsari, S. (2013). Pengaruh Akuntabilitas, Kompetensi, Professionalisme, Integritas, dan Objektivitas Akuntan Publik Terhadap Kualitas Audit Dengan Independensi Sebagai Variabel Moderating. Jurnal Akuntansi \& Auditing, 10(1), 68-92.

Hom, P. W., Tsui, A. S., Wu, J. B., Lee, T. W., Zhang, A. Y., Fu, P. P., \& Li, L. (2009). Explaining Employment Relationships With Social Exchange and Job Embeddedness. Journal of Applied Psychology, 94(2), 277-297. https://doi.org/10.1037/a0013453 
Hussein, H. S. A., Said, R. M., Abdullah, A., \& Mat Daud, Z. (2016). The impact of organizational culture on corporate performance. Walden Universiity, $V(8)$, 585-597. Retrieved from http://ijecm.co.uk/

Junaidi, Hartono, J., Suwardi, E., Miharjo, S., \& Hartadi, B. (2016). Does auditor rotation increase auditor independence? Gadjah Mada International Journal of Business, 18(3), 315-336. https://doi.org/10.22146/gamaijb.16988

Kimberly, F. C., \& Jhordan, L. (2008). Skeptisim and The Management Accountant Insight for Fraud Detection. Management Accounting Quarterly, 9(2), 9-15.

Koroy, \& Ramayana, T. (2008). Pendeteksian Kecurangan (fraud) Laporan Keuangan oleh Auditor Eksternal. Jurnal Akuntansi Dan Keuangan, 10(1), $22-23$.

Kurniawan, G. (2013). Pengaruh Moralitas, Motivasi dan Sistem Pengendalian Intern terhadap Kecurangan Laporan Keuangan (Studi Empiris pada SKPD di Kota Solok, (September), 30.

Mapuasari, S. A. (2017). The Ethics of Professional Skepticism: A Study in Indonesia Supreme Audit Institution. Journal of Applied Accounting and Finance, 1(1), 1-11.

Mulyadi. (2013). Auditing Buku 1 (6th ed.). Jakarta: Salemba Empat.

Putra, S. W. (2015). Pengaruh Komitmen Organisasi, Budaya Organisasi, Gaya Kepemimpinan Dan Lingkungan Terhadap Kinerja Karyawan Pada Industri Kecil. Jurnal Ekonomi MODERNISASI, 11(1), 62-77. Retrieved from http://ejournal.unikama.ac.id/index.php/JEKO/article/view/869

Raya, C. I. (2016). Pengaruh Independensi dan Skeptisme Profesional terhadap Pendektesian Kecurangan. Universitas Hassanuddin.

Saifulloh, A. (2016). Pengaruh Skeptisisme terhadap Konsep World Theology dan Global Theology. Kalimah, $11(1), \quad 213$. https://doi.org/10.21111/klm.v11i1.209

Sapariyah, R. A. (2011). Pengaruh Good Governance Dan Independensi Auditor Terhadap Kinerja Auditor Dan Komitmen Organisasi (Survey Pada Kantor Akuntan Publik Di Surakarta). Jurnal Ekonomi Bisnis Dan Perbankan, 19(16).

Saputra, W. (2015). The Impact Of Auditor 's Independence On Audit Quality: A Theoretical Approach. International Journal of Scientific \& Technology Research, 4(12, DECEMBER 2015), 348-353. 
Sedarmayanti. (2009). Sumber Daya Manusia dan Produktivitas Kerja. Bandung: CV Mandar Maju.

Shore, L. M., \& Wayne, S. J. (1993). Commitment and employee behavior: Comparison of affective commitment and continuance commitment with perceived organizational support. Journal of Applied Psychology, 78(5), 774-780. https://doi.org/10.1037/0021-9010.78.5.774

Suraida, I. (2005). Pengaruh Etika, Kompetensi, Pengalaman Audit dan Risiko Audit terhadap Skeptisisme Profesional Auditor dan Ketepatan Pemberian Opini Akuntan Publik. Sosiohumaniora, 7(3), 186-202.

Susanto, Y. K. (2017). The Determinant on Job Satisfaction Among Auditor. South East Asia Journal of Contemporary Business, Economics and Law, 13(2), 67-70.

Toba, Y. (2011). Toward a Conceptual Framework of Professional Skepticism in Auditing. WASEDA Business \& Economic Studies, (47), 34. Retrieved from https://dspace.wul.waseda.ac.jp/dspace/bitstream/2065/35707/1/WasedaBusi ness\%26EconomicStudies_47_Toba.pdf

Tresno Eka Jaya, Irene, C. (2016). Skepticism, Time Limitation of Audit, Ethics of Professional Accountant and Audit Quality (Case Study in Jakarta, Indonesia). Review of Integrative Business and Economics Research, 5(3), 173-182. Retrieved from http://sibresearch.org/uploads/3/4/0/9/34097180/riber_b16-105_173-182.pdf

Tri, W. (2013). Pengaruh Independensi, Gaya Kepemimpinan, Komitmen Organisasi, dan Pemahaman Good Corporate Governance terhadap Kinerja Internal Auditor (Studi pada PT Bank Lampung). Sk.

Trisnaningsih, S. (2007). Independensi Auditor dan Komitmen Organisasi sebagai Mediasi Pengaruh Pemahaman Good Governance, Gaya Kepemimpinan dan Budaya Organisasi terhadap Kinerja Auditor. Simposium Nasional Akuntansi $X$.

Umi, C., Islahuddin, \& Nadirsyah. (2015). Pengaruh Sikap Skeptisme Profesional Auditor, Bukti Audit Kompeten, dan Tekanan Waktu terhadap Pendeteksian Kecurangan pada Inspektorat Aceh. Jurnal Magister Akuntansi, 4(1), 20-28.

Wan Hua, L., Georgakopoulos, G., Sotiropoulos, I., \& Galanou, E. (2014). Main Principles and Practices of Auditing Independence in China: A Multifaceted Discussion. Asian Social Science, 6(7), 3-11. https://doi.org/10.5539/ass.v6n7p3 
Ida Ayu Dhaniar Waghmi Pratami dan I Ketut Budiartha. Pengaruh ...

Warsidi, Maghfiroh, S., \& Nanda, L. (2018). The Effect of Professional Skepticism, Client Pressure, Auditor Experience, and Audit Regulation on Audit Fraud. Jurnal Ekonomi, BIsnis, Dan Akuntansi, 20(1). 